\title{
NUTRITIONAL SUPPLEMENTS IN OPTIMAL HUMAN NUTRITION
}

\author{
Maija Kronberga and Daina Kārklina \\ Faculty of Food Technology, Latvia University of Agriculture, Lielā iela 2, Jelgava, LV-3001, LATVIA; \\ maija.kronberga @inbox.Iv
}

Contributed by Daina Kārkliṇa

\begin{abstract}
The basic requirements for human health and life quality improvement are wholeness, variety and moderation in food choices. In industrial countries the numbers of adipose inhabitants is constantly growing. People consume insufficiently vegetables, fruits and fish. The missing nutrients must be augmented with the help of functional foodstuffs. The objective of the study was to compare the impact of food supplements and local products rich in fibre and polyunsaturated fatty acids on the human body. The research was conducted at the Riga Heart Consulting Room in 2010. For two months, 60 volunteers in three groups: using the food supplement "Wellness" in their diet (Wellness group), or Jerusalem artichoke (Helianthus tuberosus L.) and linseeds (Linum usitatissimum L.) (Nature group) and Control group were monitored. The participants' weight, girth, amount of glucose and level of cholesterol were measured by standard methods. Data acquired were analysed using Microsoft Excel and SPSS (level of significance $\mathrm{P}<0.05$ ). The cholesterol level was reduced by $14 \%$ in the Nature Group. Glucose normalised to $5.8 \mathrm{mmol} / \mathrm{l}$. Weight of participants was reduced by 2 to $7 \mathrm{~kg}$. The results show that by enriching the daily diet with food supplements, both as natural products and as a special complex, it is possible to reduce body weight, reduce cholesterol and glucose levels in the blood, and reduce the risks of obesity and coronary heart disease.
\end{abstract}

Key words: food supplements, Jerusalem artichoke, linseeds, cholesterol level.

\section{INTRODUCTION}

A wholesome and balanced diet, and safe and qualitative foodstuffs, are the basic requirements for human health and life quality improvement. The main criteria for qualitative food are wholeness, variety and moderation. The amount of food is less significant than its biological value, as determined by the presence of all necessary nutrients in the right proportions. The amount of food consumed must correspond to daily energy use. If the amounts of the consumed and expended energies are disproportionate for a prolonged time, the human body is not able to maintain its optimum weight, and deviation takes place. If, in previous centuries the reason for dietary imbalance was due to insufficient amounts of food, then nowadays the higher risk of illness is due to too much food, overly rich in calories.

The industrialisation of food production has changed accessibility to food, and the amounts now consumed cause many health problems. In Latvia there are very high levels of heart and coronary diseases, and the number of adipose inhabitants is constantly growing. Latvian inhabitants do not consume enough fresh vegetables, fruits and fish (Pudule et al., 2007; Mintāle et al., 2010). The missing fibre and polyunsaturated fats must be consumed additionally with the help of functional foodstuffs or special food supplements (Kaulinšs et al., 2001; Bekers et al., 2004).
Nowadays obesity is epidemic worldwide. In the United States, $20 \%$ persons suffer from obesity, in Europe, $15 \%$ (Willcox et al., 2001). Every year the number of overweight people increases. Latvia makes an effort to not fall behind in this aspect. According to a questionnaire administered in $2004,52.7 \%$ of Latvians were normal weight, overweight - 27.4\%, but obese - 19.9\% (Erglis et al., 2007).

The close connection between sickness prevention and food consumption has turned scientist attention to recommendations for a beneficial and balanced diet designed to reduce the risk of illness.

Food with high energy value but low nutritive value, combined with low physical activity, contributes to extra weight and obesity. Most people do not know or do not observe the principles of a healthy diet. The arrival of international eating traditions in Latvia has caused the consumption of atypical foods and, thus, metabolic disturbance. These factors dictate the necessity of replacing the missing food elements in the basic inferior diet with assorted food supplements.

Often weight reduction can be the decisive factor in normalising the level of fat in blood and stop the progress of sickness. Reduction of body mass mainly means a diet with lowered calorie intake and increased calorie use at high physical loads. 
A typical visitor to the Riga Heart Health Consulting Room is a person with an immobile lifestyle who is overweight and has an unbalanced diet, and who has a cholesterol level deviating from the norm. The inferior, unbalanced diet combines lack of fibre with too many fast carbohydrates and fats, as well as lacking microelements, natural vitamins, unsaturated fats and other biologically active compounds. If such a person is not motivated to correct his or her lifestyle, then dislipedemia progresses and drug-induced treatment becomes the only solution. Most people at this stage could successfully correct their risk factors with the help of diet, but do not yet realise the danger of their condition. On learning about heightened cholesterol levels, this person will try to change daily eating habits, however, soon finds it too difficult to resist favorite products in the long-term, and therefore, gives up any efforts to maintain his or her health. Some behaviours, especially where diet is concerned, are almost impervious to modification, and therefore, rapid change cannot be expected. So one of the possible options, to change one's diet completely, is not achievable for most people.

Another option is to supplement one's daily diet with nutrients that are significant for the human organism but are not present in sufficient amounts in food. To enrich one's diet would be the easiest lifestyle change.

Diet can be enriched both with foodstuffs containing the missing elements and with specially enhanced food supplements containing fibre, microelements, vitamins and bioactive compounds from vegetables. It is advisable to consume about 30-35 grams of fibre, since products rich in fibre have been proven to lower cholesterol levels.

Food enrichment can improve human well-being overall: working capacity, maintain health and improve the quality of life by reducing the risks of coronary heart disease, cholesterol levels, triglyceride and glucose measures, and weight reduction.

An alternative option is to enrich diets with natural local products that can supplement the diet with missing food elements and which are preferable for three reasons - commercial food supplements are comparatively expensive, some people prefer to use only natural foodstuffs, and many people prefer local agricultural products. In the research it was decided to use linseeds as a familiar foodstuff that is rich with polyunsaturated fats and lignans, as well as Jerusalem artichoke (Rickard and Thompson, 1997; Mazur et al., 1998). Jerusalem artichoke (Heliantus tuberosus L.) tubers are known to be health-promoting. They contain inulin instead of starch as a carbohydrate reserve. Inulin and its degraded byproduct, oligofructose, are major compounds of interest to the food industry as functional and low-calorie food materials. Many scientists have discovered that inulin has a beneficial effect on gastro-intestinal activity, stimulating reproduction of beneficial bacteria (Kaur and Gupta, 2002; Roberfroid, 2005). Jerusalem artichoke powder made from Jerusalem artichoke roots also is a valuable product, rich in inulin, as well as vitamins and minerals (Praznik et al., 2002; Cieslik et al., 2005; Gedrovica, 2012).

One final correction of dietary inadequacies can be addressed by ensuring sufficient water consumption.

Using different kinds of food supplements it is possible to reduce cholesterol and glucose levels, to reduce weight and to decrease the hazard of coronary heart diseases and obesity. The objective of this research was to compare the impact of food supplements and local products rich in fibres and polyunsaturated fatty acids on the human body.

\section{MATERIALS AND METHODS}

The research was conducted in 2010 at the Riga Heart Health Consulting Room (HHCR) in collaboration with the Latvia University of Agriculture, Faculty of Food Technology, and involved 60 volunteers. Qualitative methods observation and document analysis - were used in the research.

The visitors to the Consulting Room are chiefly people who do not have chronic diseases, who have not visited health care institutions for a long time, and who would like to know if their health indicators meet the norms.

Standardised examination was done by specially trained employees at the HHRC.

Anthropometric data - height, weight and girth. Height was measured by a Kirchner \& Wilhelm $\mathrm{GmbH}+\mathrm{Co}$ Kawe height measuring instrument, precision $0.5 \mathrm{~cm}$. Weight was measured by a medical scale made by Omron, precision $0.1 \mathrm{~kg}$ (weight was measured without footwear and in light clothes). Girth was estimated with a special measuring-tape, precision $0.1 \mathrm{~cm}$. Waist measurement was taken in the area from the pelvic bone to below the rib cage, with the abdomen relaxed, at exhalation phase.

After estimating weight and length, body mass index (BMI) was calculated according to the following formula: BMI = weight $(\mathrm{kg}) /$ height $\left(\mathrm{m}^{2}\right)$. The following data was also collected:

Physiological data - blood pressure, pulse.

Biochemical data - estimated cholesterol $(\mathrm{H})$, triglycerides and glucose concentration in the blood plasma using an Accutrend GCT device made by Roche and test strips Accutrend Cholesterol, Accutrend Glucose, and Accutrend Triglycerides.

Analyses were taken on an empty stomach (no food $8 \mathrm{~h}$ before measuring).

Subjective information was gathered in the form of a questionnaire about additional risk factors:

- adverse heredity factors: heart attack, insult, hypertension (some respondents' next of kin had diabetes mellitus before they reached 55 years of age); 
- smoking: currently or in the past. If the answer is positive then information about how many cigarettes per day and how many years of smoking;

- degree of physical activity: intensive, moderate, immobile;

- diagnosed and treated with medication for diseases such as: diabetes mellitus, arterial hypertension, fibrillation, stenocardia, heart attack / insult, dislipidemia, adiposity;

- regularly increased level of stress;

- attitude towards advice about healthy food: accepts most, accepts some, does not accept any.

For this research three homogeneous and equivalent groups with 20 participants in each group were created. All participants had increased weight/girth, and aberrant cholesterol levels. Their life style did not conform to healthy diet recommendations.

A balanced diet should contain optimum protein, fat and carbohydrate ratios, with protein comprising 10-15\%, fat $25-30 \%$, and carbohydrates $55-60 \%$, assuming a person of average physical activity ingesting $2000-2200 \mathrm{kca} / \mathrm{d}$. It is possible to ensure this by consuming $100 \mathrm{~g}$ of protein, $80 \mathrm{~g}$ of fat, and 400-500 $\mathrm{g}$ of carbohydrates daily. Human health also requires 30-35 g fibre, and 3-5 g omega 3 daily (Erglis et al., 2007).

The average research participant consumed 3120-3700 $\mathrm{kcal} / \mathrm{d}$. The total caloric intake included $13-15 \%$ protein, 40-48\% fat, and 44-48\% carbohydrates, consumed as 100-174 g protein, $145-174 \mathrm{~g}$ fat, and 366-417 g carbohydrates. Fresh fruits and vegetables were consumed once per week by $24 \%$ of participants, 2-3 times per week by $43 \%$, daily by $17 \%, 2-3$ times daily by $5 \%$, and not at all by $11 \%$. Fish was consumed 2-3 per week by $14 \%$ of participants, once per week by $38 \%, 2-3$ times per month by $28 \%$, several times per year by $6 \%$, and not at all by $14 \%$. As half of participants did not consume enough fish, the use of omega 3 supplements would compensate in maintaining a balanced diet in these cases. Fish oil was consumed year-round by $13 \%, 2-3$ times per year by $18 \%$, once a year by $12 \%$; in the event of illness, $12 \%$ remembered using fish oil; fully $45 \%$ of participants regarded fish oil as completely unnecessary. Necessary to human health is the consumption of 1.5-2 litres drinking water daily. Of the research participants, only 3\% achieved this optimal amount, $18 \%$ managed 1 litre, $46 \%$ felt 1-2 glasses of water daily was sufficient, and $24 \%$ regarded water as necessary only when taking medication. Most unsettling was the finding that $9 \%$ did not use drinking water at all, taking liquids only in the form of coffee, tea, soft drinks or beer. Insufficient fibre and polyunsaturated fat intake was recorded for $79 \%$ of participants.

The criteria of volunteer choice were: $\mathrm{BMI}>25<40, \mathrm{H}>5$ $\mathrm{mmol} / \mathrm{l}$, unbalanced diet (insufficient consumption of vegetables, fruits and water), and motivation to change lifestyle.
Division into groups was determined by their responses to the question: "Do you plan to change your lifestyle?" People who wanted to use food supplements were added into Wellness Group. People who wanted to use natural products to supplement their diet were added into Nature Group. The Control Group was comprised of people sharing similar habits and health indicators, and who wanted to change their lifestyle but could not motivate themselves. All participants had to keep to their usual eating habits and were not allowed to start new diets during this two-month research period.

Food supplements used were: Wellness Pack (multivitamin \& mineral, astaxanthin, Omega3) and Natural Balance Shake (pea protein, apple powder, whole egg, whey, ground sugar beet fibre, natural vanilla flavour) by Wellness from Oriflame (Sweden). In addition to daily food intake, the Wellness Group used:

- 1 package of Wellness Pack vitamins after lunch;

- 2 portions of Nature Balance Shake before lunch and dinner (18 $\mathrm{g}=1$ measurement spoon mixed with $150 \mathrm{ml}$ of water, juice or milk);

- 1 litre of noncarbonated drinking water, in doses of 200-250 ml 30 minutes before food.

The Nature Group products were: linseeds and linseed oil by „Viza Oil Group” (Latvia), and Jerusalem artichoke powder by "Herbe" (Latvia). The Nature Group additionally used daily:

- $20 \mathrm{~g}$ Jerusalem artichoke powder $(10 \mathrm{~g}$ inulin $)=1$ tablespoon mixed into drink or food;

- 10 g linseeds = 1 teaspoon;

- $10 \mathrm{ml}$ linseeds oil =1 teaspoon;

- 1 litre of noncarbonated drinking water, in doses of 200-250 $\mathrm{ml} 30$ minutes before food.

The Control Group used daily food without change.

Each research participant received a code ensuring anonymous participation and a registration card containing HHCR standard research data:

- anthropometric - length, weight and girth;

- physiological - blood pressure, pulse;

- biochemical - glucose, cholesterol and triglycerides;

- completed questionnaire about eating habits;

- volunteer's written agreement to participate in the research project.

During the two-month research period, food supplement usage data was collected repeatedly at HHCR using the same instruments and recording the results on each participant's card. 
Data acquired during the research was processed using Microsoft Excel and SPSS.

All results were evaluated using a level of significance $P<$ 0.05 .

The author has received the permission of the RSU (Rìga Stradiņš University) Ethics Committee to conduct biomedical research, and each volunteer subject has given his or her written, informed consent to participate in this research.

\section{RESULTS}

Measurements at the beginning of research: The average body mass of the participants in the beginning of the control period was $83.5 \pm 1.7 \mathrm{~kg}$. Body mass was similar for both experiment groups. In the Wellness Group the average weight was $80.9 \pm 3.5 \mathrm{~kg}$, in the Nature Group $-81.1 \pm 2.2$ $\mathrm{kg}$, and in the Control Group the body mass was slightly higher $-88.4 \pm 2.1 \mathrm{~kg}$; however, body mass fit within the allowed deviation of $10 \%$. All the participants (weight ranging from 57 up to $116 \mathrm{~kg}$ ) were overweight and some were already obese. BMI for all participants exceeded $25-$ in Wellness Group the average BMI was 28.7, in the Nature Group the average BMI was 29.7. The maximum BMI was registered for two participants in the Wellness Group 38.4. Girth is one of the most significant indicators signalling clinical obesity and heart/coronary disease risk. On average, the girth of research participants came to $100 \mathrm{~cm}$. The girth in the Wellness Group and Nature Group varied from the accepted 88 centimeters up to 114 centimeters.

Cholesterol levels in the blood in the Wellness Group were, on average, $6.07 \pm 0.07 \mathrm{mmol} / \mathrm{l}(5.28-7.41)$, and in the Nature Group, on average $6.0 \pm 0.11 \mathrm{mmol} / \mathrm{l}(5.48-6.81)$.

For some of the research participants, along with dislipedemia, initial glucose tolerance disturbances with slightly increased readings $(5.9-6.4 \mathrm{mmol} / \mathrm{l})$ were also detected. Experience has shown that quite often excess weight and dislipedemia facilitate development of diabetes mellitus type 2. Also, triglyceride levels for several participants were too high, on average $-2.1 \mathrm{mmol} / \mathrm{l}$ instead of the recommended $1.7 \mathrm{mmol} / \mathrm{l}$.

Measurements at the conclusion of study period were repeated, and new body mass indicators were obtained: in the Wellness Group - 77.2 $\pm 3.4 \mathrm{~kg}(53-105 \mathrm{~kg})$, in the Nature Group - 76.4 $\pm 2.1 \mathrm{~kg}(61-99 \mathrm{~kg})$, and in the Control Group $-88.35 \pm 2.9 \mathrm{~kg}(67-117 \mathrm{~kg})$ (Fig. 1). During the research period, the average body mass loss in Nature Group for each participant was about $4.7 \mathrm{~kg}$. The biggest loss of a single individual's weight was $7 \mathrm{~kg}$, and in general participants lost from 2 to $7 \mathrm{~kg}$ of excess weight.

Seven people reached normal BMI $<25$, but six participants reduced their weight, on average to BMI of 27.9. Representatives of the Nature Group on average lost $4.35 \mathrm{~cm} \pm$ $0.25 \mathrm{~cm}$.

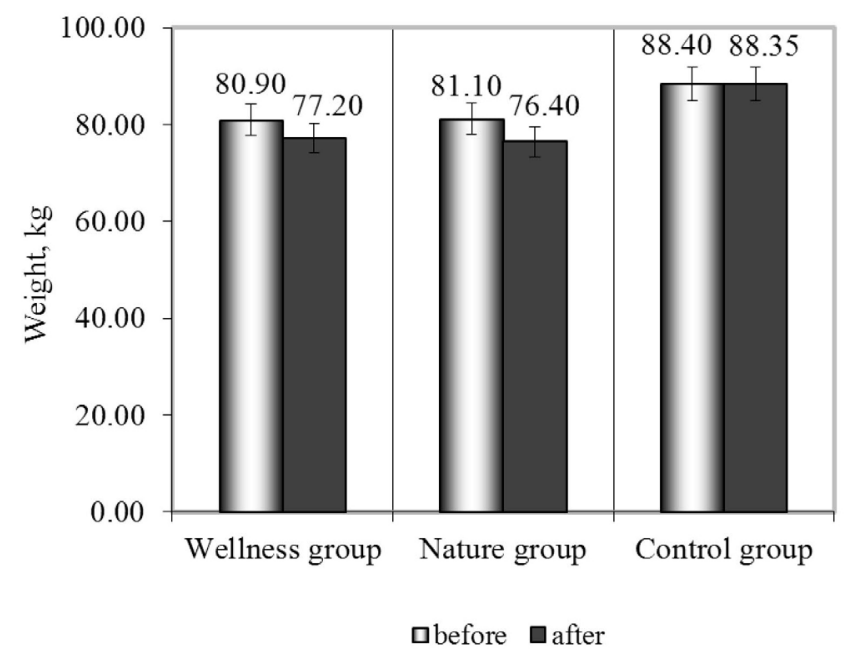

Fig. 1. Body mass at the beginning and end of the study period.

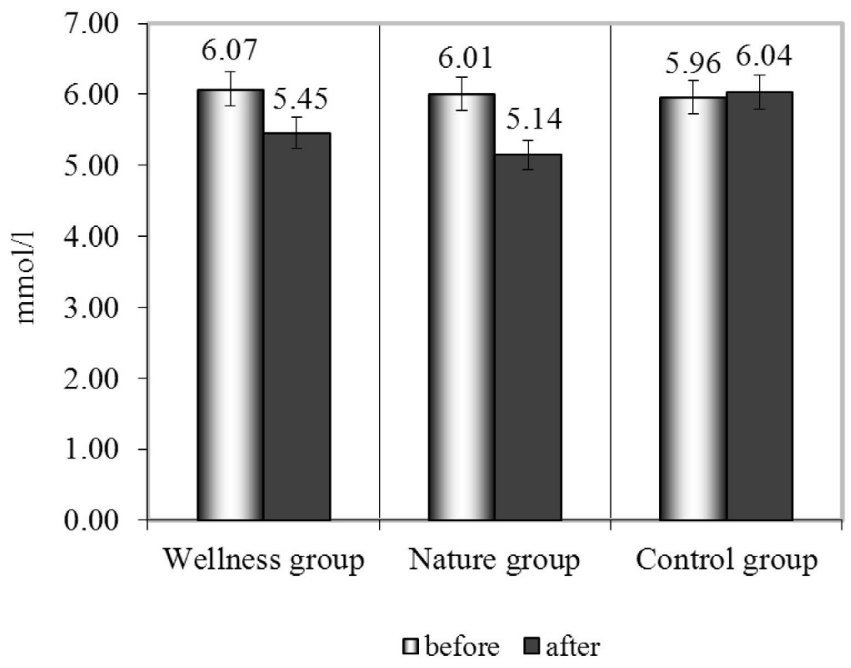

Fig. 2. Cholesterol level at the beginning and end of the study period

Cholesterol readings were reduced most in the Nature Group, on average by $0.86 \mathrm{mmol} / \mathrm{l}$, which proves the close connection between weight reduction and regulation of lipid levels. The average cholesterol measurement in the Nature Group was $5.14 \mathrm{mmol} / \mathrm{l} \pm 0.07$. As a result, all groups left the risk group. Also, in the Wellness Group there was a reduction by $0.62 \mathrm{mmol} / \mathrm{l}$, to average cholesterol level of 5.45 $\mathrm{mmol} / \mathrm{l} \pm 0.11$ (Fig. 2). No glucose disturbances were registered for any of the participants.

Results obtained during the research were registered in individual protocols, entered into a computer and analyzed with methods of mathematical statistics. The methods used were: analyses of case absolute and relative frequency, tests of independent selections and pair selection, analyses of variance (ANOVA), linear correlation and regression analyses.

At the onset of the research, the groups were similar in body mass, with a variations coefficient of $5-10 \%$. The difference is not big, which indicates the similarity of body mass. Since the groups at onset were similar, it is possible to compare the average changes during the research period. 
The parametric Pearson method of paired linear correlation analyses indicated a relationship between body mass and girth and BMI in all groups. Correlation analyses showed a strong correlation between body mass, girth and BMI at the outset of the research, both in the Wellness Group $(\mathrm{r}=0.81$; $P=0.01)$, Nature Group $(\mathrm{r}=0.78 ; P=0.01$ and $\mathrm{r}=0.67$; $P=0.01)$ and in the Control Group $(\mathrm{r}=0.76 ; P=0.01$ and $\mathrm{r}=0.78 ; P=0.01)$. The same correlation was oberved at the end of the study period $(\mathrm{r}=0.99 ; P=0.01)$.

Cholesterol levels showed explicit correlation between cholesterol level at the beginning of the research and at the end of the research, both in the Wellness Group $(\mathrm{r}=0.85 ; P=$ $0.01)$ and Nature Group $(\mathrm{r}=0.96 ; P=0.01)$. A not so explicit correlation was showed by girth $(\mathrm{r}=0.43 ; P=0.05)$. Correlation of cholesterol level and body lacked statistical significance $(P>0.05)$, indicating that a person can carry excess weight for a long time before metabolic changes start, developing over time into dislipedemia.

The indicators of glucose at the end of the period were correlated with glucose indicators at the onset of the research ( $\mathrm{r}=0.69 ; P=0.01)$, and slightly with cholesterol indicators in the beginning $(\mathrm{r}=0.47 ; P<0.05)$ and in the end $(\mathrm{r}=$ $0.56 ; P=0.01$ ), as disturbances of glucose norms are related to cholesterol production in the liver.

\section{DISCUSSION}

During the two-month study period, the participants' average results improved in all aspects. At the conclusion of the research, improvement in cholesterol levels was by $14 \%$ in the Nature Group and 10\% in the Wellness Group.

Body mass loss by the end of the study in the Nature Group was by $6 \%$, in the Wellness Group, $5 \%$ from the initial weight. Summarising the results, it is obvious that in the Nature Group the average results improved in all readings and the increases were statistically valid $(P<0.05)$. Expressed by absolute numbers this $10-14 \%$ loss corresponds to $6-8 \mathrm{~kg}$ of mass, which actually is not large, but, considering the fact that such results were achieved without any diets restricting calories and amount of food, the success is convincing.

At the conclusion of the study, the difference between average results was statistically significant but the percent improvement in the Nature Group in comparison to the Wellness Group is higher in three parameters.

The total body mass loss was less than $11 \%$, which, evaluated separately is not a convincing result, as weight was still in excess in all groups. However, they are optimistic as the results came closer to the recommended norms for health. Furthermore, loss of $10 \%$ excess weight reduces heart disease and diabetes mellitus development risk by $20 \%$. Glucose had normalised for all participants to $5.8 \mathrm{mmol} / \mathrm{l}$, corresponding to the norm.
All observed changes are statistically significant for body mass and cholesterol reduction, but change in cholesterol level was nor significantly correlated with body mass loss. This indicates that changes of cholesterol level cannot be regarded as a consequence of regular overeating but as a kind of organism illness manifestation. This is confirmed by comparing the changes between the experimental research groups and Control Group at the end of this experimental research. At the beginning of the study there were no statistical differences between the Nature Group, Wellness Group and Control Group, but at the end of the study differences were observed in three indicators.

Using food supplements, Wellness products and natural products, led to significant changes in the studies indicators $(P<0.05)$. The food supplement "Wellness" and local products rich in fibre and unsaturated fatty acids (Jerusalem artichoke and linseeds) demonstrated positive effect on human health and in a natural way reduced adipositivity and dyslipidemia. The results acquired during the study confirmed the hypothesis of this paper, i.e. by enriching daily diet with food supplements both as natural products and as a special complex it is possible to reduce body weight, reduce cholesterol and glucose levels in blood, and reduce the hazards of coronary heart disease and obesity.

Several research participants expressed interest in continuing the use of the supplements they learned about through the research in their daily diet and even to reconsider the option of changing their diet altogether. After two months, the idea of health improvement through healthy food was not so scary anymore. Observing the results of the other two groups, and knowing that this method is neither difficult nor complex for users, some of the research participants expressed an interest in starting the use of food supplements and healthy products in their own daily diets. Most convincing was their own negative result.

Dietary habits often are mechanisms of psychological problem reduction, and rapid change is regarded as a violent interruption that raises stress levels and provokes a desire to stop lifestyle corrections. Unlike the traditional weight loss approaches, participants were not restricted from their habitual foods and all volunteers were very cooperative during the study. Most probably a gradual change in old habits will give positive long-term result. The best indicators of the success of this approach were shown by Nature Group, which used powdered Jerusalem artichoke together with food, linseeds and linseed oil - they not only lost $4 \mathrm{~kg}$ on average, but also reduced cholesterol levels until the norm was achieved, and completely balanced their glucose levels. The most significant result was achieved in preventive education, since the greater number of the participants expressed their wish to continue the improvements in their lifestyles both by continuing consumption of Jerusalem artichoke, linseeds and vitamins and by analyzing their diet and making healthy corrections in it - more water, vegetables, fruits and fish. This study allowed people to understand that less food can be sufficient and that changes are not so difficult. In this case, the researchers can regard the stated tasks 
as fulfilled. Furthermore, the mission of the Health Centre food consultant is also fulfilled because the most difficult task is to make people think and act.

The obtained results show that comparing the impact on the human organism of the "Wellness" dietary supplement to the impact of local products rich in fibre and polyunsaturated fats — artichokes and linseeds — both appear to benefit and strengthen human health, resulting in the reduction of obesity and dislipidemia.

The conclusion is that since local products - artichoke, linseeds, linseed oil - both as consumables and as food enrichment products are much less expensive than commercially prepared supplements, it would appear to be more important to promote local products, and hope that people can be convinced to use them in their daily diets.

\section{ACKNOWLEDGEMENTS}

ESF project "Support for the Implementation of LLU Doctoral Studies" contract No. 2009/0180/1DP/ 1.1.2.1.2/09/ IPIA/VIAA/017.

National Research Programme "Sustainable Use of Local Resources (Earth, Food, and Transport) - New Products and Technologies (Nat Res)" (2010-2013), Project No. 3. "Sustainable Use of Local Agricultural Resources for Development of High Nutritive Value Food Products (Food)”.

\section{REFERENCES}

Bekers, M., Marauska, M., Grube, M., Karklina, D., Duma, M. (2004). New prebiotics for functional food. In: Acta Alimentarica, 33 (1), 31-37.

Cieslik, E., Kopec, A., Praznik, W. (2005). Healthly properties of Jerusalem artichoke flour (Helianthus tuberosus L.). Electronic J. Pol. Agr. Univ., 8
(2). http://www.ejpau.media.pl/volume8/issue2/art-37.html (accessed 8 December 2011).

Erglis, A., Kalvelis, A., Lejnieks, A., Dzērve, V., Latkovskis, G., Mintāle, I., Zakke, I., Rasa, I. (2007). Kardiovaskulāro slimību profilakses vadlīnijas [Cardiovascular Disease Prevention Guidelines]. Rīga: Latvijas Kardiologu biedrība. 126 lpp. (in Latvian).

Gedrovica, I. (2012). Ar kaltēta topinambūra (Helianthus tuberosus L.) pulveri bagātināti miltu konditorejas izstrādājumi [Pastry products enriched with dried Jerusalem artichoke (Helianthus tuberosus L.) powder]. Doctoral dissertation, Latvia University of Agriculture, Jelgava, Latvia (in Latvian). 177 lpp.

Kauliņš, U., Kārkliņa, D., Dūma, M., Melngalve, I., Skudra, L., Krūmiṇa, G. (2001). Uzturs un tā bagātināšana [Food and Nutrition Enrichment]. Jelgava: LLU 168 lpp. (in Latvian).

Kaur, N., Gupta, A. K. (2002). Applications of inulin and oligofructose in health and nutrition. J. Biosci., 27, 703-714.

Mazur, W. M., Duke, J. A., Wähälä, K. (1998). Isoflavonoids and lignans in legumes: Nutritional and health aspects in the human. J. Nutr. Biochem., 9, 193-200.

Mintāle, I., Ērglis, A., Dinne, A., Bajāre, I., Kalvelis, A., Latkovskis, G., Jēgere, S., Taluts-Dzērve, V., Zakke, I. (2010). Sirds un virtuve [Heart and Kitchen]. Rīga: Inovatīvās medicīnas centrs. 141 lpp. (in Latvian).

Praznik, W., Cieslik, E., Filipak-Florkiewicz, A. (2002). Soluble dietary fibres in Jerusalem artichoke powders: Composition and application in bread. Nahrung/Food, 46 (3), 151-157.

Pudule, I., Villeruša, A., Grīnberga, D., Velika, B., Tilgale, N., Dzērve, V., Zìle, S., Konttinen, H., Prattala, R. (2007). Health Behaviour Among Latvian Adult Population, 2006. Helsinki: Julkaisija-Utgivare-Publisher. 164 pp.

Rickard, S. E., Thompson, L. U. (1997) Phytoestrogens and Lignans: Effects on Reproduction and Chronic Disease. In: Antinutrients and Phytochemicals in Food. Chapter 16 (pp. 273-293). American Chemical Society.

Roberfroid, M. (2005). Inulin-Type Fructans. Functional Food Ingredients. Boca Raton, Florida: CRC Press. 359 pp.

Willcox, B. J., Willcox, C., Suzuki, M. (2001). The Okinawa Program. New York: Clarkson/PotterPublishers. 538 pp.

\section{UZTURA BAGĀTINĀTĀJI CILVĒKA OPTIMĀLA UZTURA IZVEIDĒ}

Mūsdienu cilvēka uzturs nav sabalansēts, jo ar pārtikas produktiem uzṇemtais škiedrvielu un polinepiesātināto taukskābju daudzums ir nepietiekams. Sabalansētu uzturu nodrošināt cilvēkam ir vieglāk, savu diētu papildinot ar uztura bagātinātājiem, tādējādi uzṇemot trūkstošās vai nepietiekamā daudzumā organismā esošās uzturvielas. Pētījums veikts Rīgas Sirds veselības kabinetā 2010. gadā, iekḷaujot 60 brīvprātīgas personas, kurām reǧistrēts palielināts svars/apkārtmērs, holesterīna līmeņa novirzes un veselīga uztura ieteikumiem neatbilstošs dzīvesveids. Divu mēnešu ilgā eksperimentā, lietojot uzturā divu veidu uztura bagātinātājus — "Wellness" un ar šķiedrvielām un nepiesātinātām taukskābēm bagātus vietējos produktus - linsēklas (Linum usitatissimum L.), no tām gatavotu eḷıu un topinambūra (Helianthus tuberosus L.) pulveri — konstatēts, ka, lietojot vietējās izcelsmes uztura bagātinātājus, eksperimentā iekḷauto dalībnieku masa samazinājās par 4 līdz 7 kg, bet ar uztura bagātinātāju "Wellness" — no 3 līdz 8 kg. Pētījuma laikā eksperimenta dalībniekiem samazinājās holesterīna un glikozes līmenis. Būtiski, ka vietējās izcelsmes uztura bagātinātāji ir lētāki, salīdzinot ar rūpnieciski ražotajiem uztura bagātinātājiem „Wellness”. Rezultāti parādīja, ka vietējās izcelsmes uztura bagātinātājus ir iespējams veiksmīgi izmantot uzturā ar mērḳi organismā samazināt holesterīna un glikozes līmeni asinīs, kā arī cīṇai ar lieko svaru, tādējādi samazinot sirds asinsvadu slimību un aptaukošanās risku. 